\title{
Business English Education Developments in Chile
}

\author{
Xuemei Lu \\ School of Foreign Languages, Guangzhou College of Commerce, Guangzhou, China \\ Email: 1129498654@qq.com
}

How to cite this paper: Lu, X. M. (2022). Business English Education Developments in Chile. Open Journal of Social Sciences, 10, 315-323.

https://doi.org/10.4236/jss.2022.101025

Received: December 28, 2021

Accepted: January 23, 2022

Published: January 26, 2022

Copyright (อ 2022 by author(s) and Scientific Research Publishing Inc. This work is licensed under the Creative Commons Attribution International License (CC BY 4.0).

http://creativecommons.org/licenses/by/4.0/

\begin{abstract}
English as a lingua franca has more international presence fueled by the relentless forces of globalization. Demand for interdisciplinary talent who grasps business knowledge and has English language proficiency continues to grow across different countries. This paper studies the business English education in Chile by reviewing the business English education developments in Chile, delineating the status quota of Chilean business English education and analyzing the future trends. This paper has found that private language centers, foreign culture and education organizations, and higher education institutions work together to push forward business English development in Chile. It aims to have implications for the research into business English developments in Latin America and country-specific business English studies.
\end{abstract}

\section{Keywords}

Business English Education, Chile, Country-Specific Studies

\section{Introduction}

Chile is a country in the western part of South America. It occupies a long, narrow strip of land between the Andes to the east and the Pacific Ocean to the west. Chile was the first South American country to join the Organization for Economic Cooperation and Development (OECD) on 7 May 2010. For all English lacking historical and cultural ties to South American countries, it has become their most taught foreign language since the last century, and Chile is no exception. Of the Latin American regions, Chile boasts an open market economy, a high-level education, and advanced private schools. Despite the global downturn of 2008-2009 and a devastating earthquake and tsunami in 2010, Chile has remained one of the most successful economies in Latin America (OECD, 2012). Chile is at the forefront of Latin American higher education, with all re- 
levant indicators being high. Against the backdrop of globalization, countries lust for more English-speaking professionals so as to be active participants in international competition and governance. Therefore, the Chilean government has taken a series of measures to popularize English to help it better "go global". In the last 25 years, Chile has embraced public discourse aiming to become a "bilingual" country (Glas, 2008). Thus, it is of significance to look into business English education developments in Chile, which can provide references for the study of business English education in Latin America, thus promoting the country-specific study of business English.

Chile represents one of the high education levels in Latin America. Chile's educational system, structured along the lines of 19th-century French and German models and highly regarded among Latin American countries, is divided into preschool education, primary education, secondary or vocational education, and tertiary education. Higher education depends on the results of college entrance examination and the students' willingness to further study or set to work. There are two terms for each academic year, with the first term starting from early March to mid-July and the second term from early August to late November (or early December). There is typically a break of two weeks between term, followed by a summer break which lasts about two and half a month.

\section{Business English Education in Chile}

\subsection{Chile's Education System}

Preschool education is primarily designed for children between the ages of 3 and 5 . It is divided in nursery $(0-2)$, early childhood education $(2-4)$ and the transition period (4 - 6). Pre-school is voluntary, however, constitutional reform in 2013 makes it possible that all children are required to enter primary school or basic education (Enseñanza básica) where they must remain for the following 8 years. It is mandatory for children to receive an eight-year primary education in Chile, and they generally begin primary school at the age of six. Secondary education consists of scientific-humanist (regular), technical-professional (vocational) and artistic education, all lasting four years. While these three kinds of schooling are same in the first two years, they are differentiated in the last two years according to the orientation of the school. As to the vocational schools, they are classified into industrial schools, commercial schools, technical schools, and polyvalent schools. After graduation, students choosing the vocational branch can go to work or continue further studies in universities or colleges. Compulsory education originally only covered the eight-year primary school, but a constitutional reform in 2003 made free and compulsory secondary education available for all Chileans up to 21 years of age. This ensured twelve years of compulsory schooling, which was an unprecedented milestone in Latin America at the time. For all the free basic education provided by public secondary schools, Chilean education is de facto extremely polarized due to the privatization of education. There is a dearth of educational resources like teaching facilities and 
teachers in public schools. Owned by religious congregations, ethnic groups (such as German, French, Italian, and Israeli), and private educators, private schools enjoy relatively high enrollments and cater to affluent families.

Although higher education in Chile is not compulsory, the secondary education degree is a perquisite for access to tertiary education. The higher education system is a combination of public and private universities, private professional institutes and private technical training centers. Higher education in Chile is of considerable renown throughout Latin America. Chile is home to some of the top universities in Latin America, including two (Pontifical Catholic University of Chile and University of Chile) within the top 10 of the QS Latin America University Rankings 2018, while 11 universities in Chile are featured in the QS World University Rankings 2018. All universities adopt a single admission system called PSU (Prueba de Selección Universitaria, "University Selection Test"), which is designed and evaluated by the University of Chile. This incorporates mandatory examinations in maths and language, as well as other course-specific ones. Higher education institutions may be autonomous or non-autonomous. When an institution is first established, it needs to seek permission to the Ministry of Education and CNED (Consejo Nacional de Educación) and go through the licensing process. CNED will monitor the new institution and take responsibility for its awards for a period, not less than 6 years and not longer than 11 years. Also, it is CNED that determines if the institution has developed in accordance with its stated objectives and can either become autonomous or has to close down (OECD, 2012).

\subsection{Business English Education Developments in Chile}

As one of the fastest-growing economies in the Latin America, Chile has overwhelming advantages in terms of its business environment. Chile's economy features its heavy reliance on foreign trade, and it takes the lead in putting forward "regional openness". In 2003, it was the first South American country to sign a free trade agreement with the United States. English serves as the language bridge in the international economic and cultural exchange, and this also applies to Chile. Demand for English Language Teaching (ELT) in Chile is strong, largely driven by the need for English-speaking professionals, academics, and technicians to staff its increasingly internationalized industries. In this context, learning English is a naturally stylish activity that benefits both the individual and the country (Rohter, 2004). In the 1990s, a liberal economic policy, coupled with a stable political environment, led to rapid economic development and a growing number of Chileans engaged in international business activities. English plays an increasingly prominent role in business activities. Consequently, a number of versatile people with a combination of business management knowledge and English skills are fervently embraced by multinational companies. Currently, Chile is still one of the most attractive nations for investors and business people. Over the past decades, Chilean government and banks have taken 
measures to help SMEs go global. Amid the international business communication, the role of language can never be underestimated and courses related to intercultural business communication should be offered (Beadle, 2001).

English proficiency is considered as an essential skill for employment prospects. A study in 2004 revealed that students directly associated English language proficiency with improved opportunities, which got strong support from parents and teachers (93\% and $88 \%$, respectively) (Centro de Investigación y Desarrollo Educativo, 2004). Thus, Chilean universities offer English language training programs. Due to the advancement of private education in Chile, the English level of college students varies, with students from private high schools generally having a higher level of English than those from public schools. Upon entry university, students of all majors are required to take an English level test. The English level is measured on the scale from one to six based on the English test scores, with level one being the lowest, and level six being the highest (Wang, 2013). Many European immigrants were settled in South America, and thus many residents of South America are now the descendants of European immigrants. Hamel (2013) argues that multiple foreign languages options in Latin America, English included, are related to the local ethnic composition. In the 20th century, English replaced French as the dominant language in multilingual education in Latin America. This policy is a move toward a fuller integration with the global economy.

Since the 1980 reform, the Chilean business community has been an active participant of education, providing specialized training for the workforce (Carlson, 2002). In 2005, with joint efforts of the Ministry of Education, the Consultative Business Council was established to make education better underpin the national economy and in line with globalization. Within the framework of "Education and business: Agenda for growth II", the Council has taken several educational measures, including the push for improved English for specific purposes. For instance, CORFO (Corporación para el Fomento de la Producción), a business services company, acts as a medium between professionals with English skills and foreign recruitment companies. On its official website, applicants' English proficiency level is divided into four levels so that employers can better select candidates. The British Council survey results revealed that about 30 percent of companies offered English training opportunities for their employees. A majority of employers considered English language skills very important for management staff, while $48 \%$ regarded English language proficiency is an essential skill for staff (British Council, 2015).

\subsection{Business English Education Policies in Chile}

Chile is a pioneer of neoliberal economic reform in Latin America, which has also deeply influenced the reform and development of education (Yuan, 2008). Chilean government's foreign language reforms have promoted the development of business English. Since the 1990s, Chilean higher education had developed rapidly, and college had been in align with global development. In order to 
promote the modernization and improve the quality of higher education, the Chilean Ministry of Education included internationalization as one of the four main strategies of the higher education policy framework in 1997. Since then, the number of international students in Chile had been growing over the last two decades. Some schools implemented high-quality, multidisciplinary educational programs and short-term study visits such as intercultural educational programs to meet the diverse needs of foreign students (Carlos, 2005). Apart from the Ministry of Foreign Affairs, the international Cooperation of the (Agencía de Cooperación Internacional de Chile, or AGCI) is responsible for identifying priority international cooperation programs that are in line with Chile's national development orientation and providing financial support for these programs. For example, international students studying in Chile or Chilean students studying abroad can be granted scholarship, as well as technical and vocational training (Feng, 2016).

Previously, English language education in Chile was exclusive to the elite who were educated in private schools. Therefore, in order to make English education more accessible and education equitable, the Ministry of Education carried out foreign language education reforms in 1998. The reform syllabus specifies that 40 percent of the English curriculum is to be devoted to developing reading comprehension and listening comprehension, and 20 percent to speaking and writing, which is to better partake in global economic governance and share the convenience of information networks (Mckay, 2003). Given that Chile had already signed free trade agreements with Canada, the United States, the European Union and South Korea, the Ministry of Education launched the English Opens Doors Program in 2003 as part of an agreement with the United Nations Development Program (UNDP). The program was planned to be initiated in the fifth grade of elementary school and students were expected to reach B1 level under the Common European Framework for Languages after graduation. However, English language instruction in higher education had been covered. The program was initially to be launched until 2012, but the timeframe had been extended. This English policy aims to improve national economic competitiveness and promote equitable access to English learning in public schools (Matear, 2008). In other Latin American countries, mandatory English language learning would inevitably lead to resistance for fear that it would undermine national sovereignty and cultural identity. Hence, the Ministry of Education has also attempted to localize English language instruction by creating its own English curriculum and materials like Go for Chile. Although the program was designed for young students, the Chilean government also hoped to include adults and encouraged companies to provide employees with English courses and tax exemptions.

\subsection{Business English Programs in Chile}

Business English programs in Chile are mainly offered in higher education institutions, private language centers and British and American culture and educa- 
tion organizations, while there are significant differences in terms of the teaching approaches.

Business English program is not available in public universities, and the English-related programs are basically English Language and Literature (Licenciatura en Lingüística y Literatura Inglesas) and English pedagogy (Pedagogía en Inglés). Nonetheless, business English courses are incorporated into the curriculum of the English program. For example, students specializing in English language and literature of the University of Chile and the Pontifical Catholic University of Chile can get access to the course intercultural communication, which can enhance their intercultural communication abilities. They also offer applied linguistics courses such as discourse and pragmatics (Discurso y pragmática) and multimodal communication (comunicación multimodal) to develop students' linguistic analysis and pragmatic skills. In addition, universities such as the University of Concepción and the Pontifical Catholic University of Valparaíso design compulsory business English writing to help students navigate changes in the workplace. Overall, most Chilean universities have added business English to the curriculum of business programs by offering communicative English from the first year to the third or fourth year (the average year of study in Chile is five years), with the aim of training interdisciplinary business professionals for the globalized world.

Business English language training, along with traditional English language training, are offered in some language training centers. For example, Business English Advisory, located in the capital city of Santiago, has provided business English training service for local national and multinational companies including the following: business English courses (Cursos de Inglés de Negocios), business case study courses (Cursos de Inglés de Estudios de Casos de Negocio). All courses are divided into 6 levels according to the Common European Framework of Languages (CEFR): A1, A2, B1, B2, C1, and C2. A maximum of 5 students are included in each group in a bid to guarantee the teaching quality. Each course material is selected based on the specific characteristics and students' needs analysis. The Business English teaching coursebooks are chosen from the Cambridge University Press or specific academic institutions. The courses are evaluated through presentations, business case studies and business negotiations. The training instructors are qualified in English language and recruited on the basis of their background in business and/or management. Furthermore, some global language education providers such as Bridge English and Wallstreet English also offer business English courses in Chile. Bridge English Center has a separate Bridge Business English Institute, which offers business English training courses. The courses are designed for business people between the ages of 20 and 50 who desire to improve their English skills and must reach Level 4. The business English courses such as English immersion and group learning are contingent on students' needs whose aim is to cultivate students' business communication skills. Bridge English Center provides business English training to companies as well. 
Wall Street English offers an online and offline learning experience, with teaching resources including Market Leader, For Today, and Financial Times. The topics covered in the course are buying and selling, managing people, ethics, mergers and acquisitions, telephone skills, interview skills, presentation skills, presentation skills, negotiation, and other business-related activities.

British and American culture and education organizations have also contributed to the business English development in Chile. The Office of English Language Programs at the U.S. Embassy in Chile offers a variety of English language programs, case in point, the "E-teacher" Scholarship Program. That is, foreign professionals are trained by up-to-date American English teaching methods through distance learning. English for Special Purposes (ESP) studies are included in the curriculum design. The British Council offers online short-term business English courses focusing on business meetings, presentations, daily business communication, job interviews, with the aim of improving the learner's English use ability in business settings.

\subsection{Business English Development Trends in Chile}

After a systematic review of the status quo and characteristics of business English development in Chile, this paper will briefly analyze its future trends. Currently, private language centers, foreign culture and education organizations, and higher education institutions work together to push forward business English development in Chile as a result of market orientation. Most of these training centers are branches of British and American language schools, thus their teaching methods follow British and American instruction model. These organizations design business English courses mainly for people in the workplace. Foreign education and culture organizations like the British Council offer similar business English courses to private language centers, while English language education is implemented in Chilean higher education institutions, which to some extent boost business English development. The programs related to Business English have followed a traditionally applied linguistics model, centering on English language proficiency, knowledge of linguistic theories. It should be noted that there is a lack of skilled English teachers who are effectively capable of teaching English at schools (Ministry of Education Observation Group for Higher Education in Mexico and Chile Private Higher Education in Mexico and Chile, 2009), let alone Business English teachers. In this context, English education policies should put more emphasis on teacher training and more English as a Foreign Language (EFL) teacher-education programs in Chile will be offered. In the future, business English in Chile will place special focus on fostering interdisciplinary business professionals to cater to the economic development. As the number of English language teaching personnel grows, business English teachers will be separated to provide intellectual support for the business English development. When business English teachers are in place, discipline construction is around the corner. 


\section{Conclusion}

Chile has seen growth and diversity in business English development, experiencing a dramatic increase in the number of English learners who share the benefits it brings. The governmental education reforms put an emphasis on improving English levels. The "English Open Doors Program" has to some degree promoted equity in education and enriched English-related disciplines and programs in Chile, but there are more than growing pains. It has been recognized that Chilean business English development is taking shape, yet needs to be improved. The inadequacy of business English instructors and the lack of professional training will remain the main obstacles to the development of business English, which can be attributed to several factors. Chile is characterized by inequity in access to education due to income gaps, hence students who excel in English language skills tend to grow up in families with privileged backgrounds and receive English instruction in private schools since childhood. The unique geographical location has brought with it several segregated communities in Chile, which has also hindered English language education. At this moment, despite the immature development of business English in Chile, it registers rapid growth and presents great opportunities and can have implications for other Latin American countries. Further research should be undertaken as to the understanding of how business English teachers are trained and how they learn to teach. Chile has been committed to deepening economic reforms to become more open to the outside world, with competitive advantages in attracting foreign investment in Latin America. There is a growing need for high-quality and interdisciplinary human resources in the globalized context. The policy consideration of these opportunities and challenges can energize the development of business English in Chile.

\section{Conflicts of Interest}

The author declares no conflicts of interest regarding the publication of this paper.

\section{References}

Beadle, M. (2001). Communication in International Business Education. Journal of Teaching in International Business, 12, 71-85. https://doi.org/10.1300/J066v12n03_04

British Council, Education Intelligence (2005). English in Chile: An Examination of Policy, Perceptions and Influencing Factors. https://ei.britishcouncil.org/sites/default/files/latin-america-research/English\%20in\%20 Chile.pdf

Carlos, R. S. (2005). The Internationalization of Higher Education in Chile. In de W. Hans, \& I. C. Jaramillo (Eds.), Higher Education in Latin America: The International Dimension (pp. 149-173). World Bank.

Carlson, B. (2002). Educación y mercado de trabajo en América Latina. Revista de la CEPAL, 2002, 123-141. https://doi.org/10.18356/2eee834c-es

Centro de Investigación y Desarrollo Educativo (CIDE) (2004). V encuesta nacional a 
actores del sistema educativo [5th survey of actors in the education system]. Universidad Alberto Hurtado.

Feng, S. (2016). Characteristics and Experience of Higher Education Internationalization. Journal of Kaifeng Institute of Education, 36, 113-116.

Glas, K. (2008). El inglés abre puertas... ¿a qué? Análisis del discurso sobre la enseñanza del inglés en Chile, 2003-2006. Revista Educación y Pedagogía, 20, 11-122.

Hamel, R. (2013). Language Policy and Ideology in Latin America. In R. Baley, R. Cameron, \& C. Lucas (Eds.), The Oxford Handbook of Socio linguistics (pp. 609-628). Oxford University Press. https://doi.org/10.1093/oxfordhb/9780199744084.013.0030

Matear, A. (2008). English Language Learning and Education Policy in Chile: Can English Really Open Doors for All? Asia Pacific Journal of Education, 28, 131-147. https://doi.org/10.1080/02188790802036679

Mckay, S. (2003). Teaching English as an International Language: The Chilean Context. English Language Teaching Journal, 57, 139-148. https://doi.org/10.1093/elt/57.2.139

Ministry of Education Observation Group for Higher Education in Mexico and Chile Private Higher Education in Mexico and Chile (2009). Investigation Report on the Development of Private Higher Education in Mexico and Chile. Journal of Zhejiang Shuren University, 9, 21-25.

OECD (Organization for Economic Co-Operation and Development) (2012). OECD Economic Surveys: Chile 2012. OECD Publishing. https://doi.org/10.1787/eco_surveys-chl-2012-en

Rohter, L. (2004, December 29). Learn English, Says Chile, Thinking Upwardly Global. New York Times. http://nytimes.com

Yuan, C. Q. (2008). Chile's Reforms on Higher Education and Its implications For China. Studies in Foreign Education, 35, 48-52.

Wang, J. (2013). A Comparative Analysis of English Teaching in Chinese and Chilean Universities. Overseas English, 16, 108-110. 